\title{
Overwintering of Calanus finmarchicus and Calanus helgolandicus
}

\author{
Hans-Jürgen Hirche
}

\begin{abstract}
Alfred-Wegener-Institut für Polarforschung, Columbus-Center, D-2850 Bremerhaven, Federal Republic of Germany
\end{abstract}
\begin{abstract}
Overwintering of Calanus finmarchicus and C. helgolandicus was studied in the field and in laboratory experiments in a shallow $(120 \mathrm{~m})$ Swedish fjord and in a deep $(650 \mathrm{~m})$ Norwegian fjord. In the Norwegian fjord 2 populations were found in late summer and autumn: in the surface layer the copepods were smaller and more active with high respiratory and digestive enzyme activities. The deep population, consisting of Copepodid stage V (CV) and a few females, was torpid, had large oil sacs and empty guts. Their respiratory and digestive enzyme activities were very low. In the Swedish fjord $\mathrm{CV}$ in deep layers weighed much less than those in the Norwegian fjord. Weight-specific respiration was intermediate between deep and surface population in the Norwegian fjord. It is concluded that overwintering copepodids do not feed. Metabolic rates allowed successful overwintering only in the Norwegian fjord. Experiments performed on several occasions during overwintering witnessed - in contrast to the situation in field populations - increased rates of respiration and moulting. Mortality during moulting and time span between capture and onset of moulting decreased during autumn and winter. These observations suggest internal development during overwintering.
\end{abstract}

\section{INTRODUCTION}

Many calanoid copepod species overwinter in deep water generally as Copepodid stage V (CV). There is, however, conflicting published information concerning the physiology and behaviour of this overwintering stage. Marshall and Orr (1958) and Butler et al. (1970) concluded from respiration and excretion measurements on Calanus finmarchicus and C. helgolandicus that, although the overwintering stages utilised little oxygen, there was a requirement for food intake during winter when phytoplankton is scarce. They therefore suggested that microzooplankton and detritus formed the overwintering-diet. Detrital feeding was also suggested by Harvey (1950) and Corner et al. (1974), while Comita et al. (1966) found increases in weight and calorific content that could only be the result of winter feeding. On the other hand, several workers failed to detect stomach contents in overwintering stages of $C$. finmarchicus (Ussing, 1938), C. hyperboreus (Conover, 1962), Calanoides acutus (Andrews, 1966), C. cristatus (Omori, 1970) and C. plumchrus (Fulton, 1973).

These contradictory findings concerning food uptake by overwintering stages possibly result from ecological differences in the respective samples or populations. Evidence for winter feeding, particularly in Calanus finmarchicus and C. helgolandicus (Marshall and Orr, 1958; Butler et al., 1970), comes from specimens caught in the upper water layer in rather shallow areas, whereas evidence for fasting stems from deep-water samples. Since $C$. finmarchicus and $C$. helgolandicus are both found in shallow waters of the Central North Sea and in the deep Norwegian Sea during winter it was possible to test whether metabolic activity and feeding are related to overwintering depth.

This paper reports in-situ measurements of respiratory and digestive enzyme activities in Calanus finmarchicus and C. helgolandicus from 2 fjords $(120 \mathrm{~m}$ and $650 \mathrm{~m}$ deep, respectively). In addition, experiments were carried out to study the influence of external stimuli such as food, light and temperature on respiration, digestive enzymes and development of copepods from different water depths.

\section{MATERIAL AND METHODS}

\section{Sampling}

Samples were obtained from the deepest part of 2 fjords, the Gullmarfjord on the Swedish west coast $\left(58^{\circ} 20^{\prime} \mathrm{N} 11^{\circ} 30^{\prime} \mathrm{E}\right.$, maximum depth $\left.120 \mathrm{~m}\right)$ and the Korsfjord near Bergen, Norway $\left(60^{\circ} 12^{\prime} \mathrm{N} 5^{\circ} 14^{\prime} \mathrm{E}\right.$, max- 
imum depth $650 \mathrm{~m}$ ) on various occasions (Table 1). A Beyer's low-speed midwater trawl (Beyer, unpubl.; mesh size $500 \mu \mathrm{m}$ ) was used to catch material. Unfortunately, this type of net has no closing device. This was, however, thought to be of no great disadvantage at either site. In the Gullmarfjord during autumn and winter virtually no $\mathrm{CV}$ of Calanus finmarchicus nor $C$. helgolandicus occurred in the surface layers although many CV's occurred in deeper waters (Hirche, in press). The net was towed obliquely from bottom to surface, hence all CV in the catch will have come from deep water. In the Korsfjord Matthews (quoted in Kirkesaether, 1977) recognized 2 distinct groups: a surface group ( 0 to $60 \mathrm{~m}$ depth) and a deep group (200 to $600 \mathrm{~m}$ ). In this study, the deep group was sampled by towing Beyer's midwater trawl horizontally on a $900 \mathrm{~m}$ warp. To minimize contamination by the surface group the net was veered and hauled as quickly as possible. The surface group was sampled with a Nansen net $(300 \mu \mathrm{m}$ mesh size). Glass jars of 11 (Nansen net) or 31 (Beyer's low-speed midwater trawl) capacity were secured in the cod end of the nets to avoid damaging the catch. The samples were immediately transferred to $10 \mathrm{l}$ buckets containing water from the respective depths. They were stored in the dark pending sorting into developmental stages under a microscope in a laboratory ashore.

\section{Homogenate preparation}

For digestive enzyme assays and for ETS, 15 to 20 individuals respectively were homogenised in $2 \mathrm{ml}$ iced distilled water using a Potter-Elvehejm Homogenizer on crushed ice. Following centrifugation at $6000 \mathrm{rpm}$ for $10 \mathrm{~min}$ the supernatant liquid was either used directly in the case of ETS measurement or deep frozen at $-20^{\circ} \mathrm{C}$ for digestive enzyme assay. Where possible, all parameters were measured from the same homogenate.

\section{ETS measurement and respiration}

From the activity of the electron transport system (ETS), according to Owens and King (1975), in-situ respiration rates can be estimated after determination of the ETS/respiration factor. All respiration values except those of freshly caught copepods from the Gullmarfjord were calculated from ETS activities. ETS activity was determined according to the procedure described by Owens and King (1975) except when using distilled water for homogenization instead of a homogenization buffer. For each duplicate assay $0.5 \mathrm{ml}$ samples of freshly prepared homogenate were used and 1 blank. On 2 occasions calibration series with the Winkler technique (cf. Conover, 1956) were run to convert the ETS activities into true oxygen respiration. A factor for ETS/respiration of 4.85 (S.D. 0.42 ) was found in 10 measurements. Respiration rates were calculated per copepod and sometimes also per unit dry weight ('specific respiration'). Dry weight was determined by drying ca. 50 individuals at $70^{\circ} \mathrm{C}$ to constant weight. ETS assays were incubated at $6{ }^{\circ} \mathrm{C}$ for all in-situ measurements and at experimental temperatures for all experiments. The temperature of the deep water in the Gullmarfjord below $50 \mathrm{~m}$ throughout most of the year (Anderson et al., 1979) and in the Korsfjord below $100 \mathrm{~m}$ (Matthews and Sands, 1973) is $6{ }^{\circ} \mathrm{C}$. In the Korsfjord the temperature in the upper $60 \mathrm{~m}$ varied from 10 to $16^{\circ} \mathrm{C}$ in August.

\section{Digestive enzymes}

Amylase activity was measured by the method of Street and Close (1965) at $\mathrm{pH}$ 6.8; trypsin was determined according to Samain et al. (1977) at pH 8.3 and $39^{\circ} \mathrm{C}$. Incubation time was $15 \mathrm{~min}$ in each case. Calibration was made with amylase (Merck 24 507) and trypsin (Merck 8214 ) from bovine pancreas. Digestive enzyme activities are given as 'specific activities', related to protein. Protein was measured after Lowry et al. (1951), with bovine serum albumin (Serva 11 930) as a standard.

\section{Experiments}

Experimental flasks were incubated at either 6 or $15^{\circ} \mathrm{C}$ and kept either in total darkness ('dark experiment') or in a $12 / 12 \mathrm{~h}$ light/dark cycle ('light/dark experiment'). Light was provided by a $20 \mathrm{~W}$ fluorescent tube $\left(5 \mu \mathrm{Em}^{-2} \mathrm{~s}^{-1}\right)$. Copepods from the Korsfjord were incubated in $500 \mathrm{ml}$ flasks. Each flask contained $40 \mathrm{CV}$ in $300 \mathrm{ml}$ of filtered seawater. Where food was added, experimental flasks contained a mixture of Skeletonema costatum and Cricosphaera carteri cultured in f/2 medium (Guillard and Ryther, 1962). Copepods from Gullmarfjord were incubated without food. For each 'dark experiment' 60 to $120 \mathrm{CV}$ were kept in 11 flasks. For 'light/dark experiments' 300 to $400 \mathrm{CV}$ were kept in 5 to 101 jars except in March, when 40 individuals were used for each experiment.

\section{Determination of species and body size}

Calanus finmarchicus GUNNERUS and C. helgolandicus CLAUS were determined in preserved samples ( $5 \%$ formalin). The curvature of the fifth swimming leg 
(P5) of CV and females, described by Rees (1949) and Fleminger and Hülsemann (1977), was used for species differentiation. Males could not be differentiated, as very often the exopodites of P5 were broken. Prosome length was taken as body length; this was measured at $25 \mathrm{x}$ magnification and read to the nearest micrometer unit $(0.04 \mathrm{~mm})$.

\section{RESULTS}

\section{Field studies}

Species distribution

In the Korsfjord only $\mathrm{CV}$ and females of Calanus finmarchicus were found, whereas in the Gullmarfjord C. helgolandicus also occurred. The species have a different seasonal distribution (Hirche, in press). In the
Gullmarfjord in June all stages belonged to C. finmarchicus, whereas in August CV were C. finmarchicus and adults $C$. helgolandicus. From September to March both species were more or less equally abundant. A fuller description of seasonal variations between the distribution of the species is given in Hirche (in press).

\section{Description of overwintering stage}

In the Gullmarfjord, from August to December $99 \%$ of the population were CV. They were found almost exclusively below $50 \mathrm{~m}$ (Hirche, in press). During the first hours after capture these CV floated motionless, with their heads upwards. Antennules were stretched backwards along the body, legs pointed forward, and the abdomen was slightly bent backwards. The

Table 1. Calanus finmarchicus and C. helgolandicus. Specific activities of trypsin $\left(10^{-4} \mathrm{U} \mu \mathrm{g}^{-1}\right)$ and amylase $\left(10^{-5} \mathrm{U} \mu \mathrm{g}^{-1}\right)$, respiration ( $\mu \mathrm{l} \mathrm{O}{ }_{2}$ ind. ${ }^{-1} \mathrm{~h}^{-1}$, direct measurement in Gullmarfjord, based on ETS in Korsfjord), specific respiration ( $\mu \mathrm{l} \mathrm{O} \mathrm{O}^{-1}$ dry weight $\mathrm{h}^{-1}$ ), dry weight $\left(\mu \mathrm{g}\right.$ ind.$^{-1}$ ) and body length $(\mu \mathrm{m})$ of Copepodid stage $\mathrm{V}$ and adults (index $\mathrm{s}=$ from surface layers, $\mathrm{d}=$ deep layers, \pm standard deviation) from two fjords

\begin{tabular}{|c|c|c|c|c|c|c|c|c|c|c|}
\hline \multicolumn{11}{|c|}{ Gullmarfjord } \\
\hline Stage & Date & $\begin{array}{l}\text { Specific } \\
\text { trypsin }\end{array}$ & $\begin{array}{l}\text { Specific } \\
\text { amylase }\end{array}$ & $\mathrm{n}$ & Respiration & $\begin{array}{l}\text { Specific } \\
\text { respira- } \\
\text { tion }\end{array}$ & $\mathrm{n}$ & $\begin{array}{c}\text { Dry- } \\
\text { weight }\end{array}$ & Length & $\mathrm{n}$ \\
\hline \multirow[t]{8}{*}{$\mathrm{CV}$} & 3. -23.5 .77 & $7.27 \pm 1.71$ & $10.82 \pm 2.76$ & 11 & & & & & $2.36 \pm 0.14$ & 154 \\
\hline & 22.-29.8.77 & 0 & $1.33 \pm 0.50$ & 6 & & & & & $2.22 \pm 0.16$ & 100 \\
\hline & 17.11 .77 & 0 & $0.87 \pm 0.11$ & 4 & $0.068 \pm 0.009$ & 0.30 & 7 & 225 & $2.23 \pm 0.17$ & 100 \\
\hline & $27.2 . / 2.3 .78$ & $0.36 \pm 0.03$ & $1.10 \pm 0.22$ & 2 & & & & & & \\
\hline & 6.10 .78 & $0.32 \pm 0.16$ & $1.05 \pm 0.11$ & 3 & $0.102 \pm 0.04$ & 0.44 & 3 & 230 & & \\
\hline & 14.12 .78 & $0.42 \pm 0.12$ & $1.42 \pm 0.08$ & 3 & $0.076 \pm 0.005$ & 0.35 & 4 & 215 & & \\
\hline & 13.6 .79 & $0.78 \pm 0.53$ & $2.63 \pm 1.30$ & 3 & $0.268 \pm 0.006$ & 1.49 & 2 & 180 & & \\
\hline & 21.3 .80 & $0.41 \pm 0.08$ & $1.75 \pm 0.44$ & 5 & $0.087 \pm 0.001$ & 0.48 & 2 & 183 & & \\
\hline \multirow[t]{4}{*}{ ㅇ } & 22.-29.8. 77 & $3.30 \pm 1.44$ & $10.72 \pm 1.62$ & 13 & & & & & $2.54 \pm 0.16$ & 34 \\
\hline & 13. 6.79 & $2.62 \pm 0.34$ & $5.83 \pm 0.82$ & 2 & $0.337 \pm 0.008$ & 1.76 & 2 & 192 & & \\
\hline & $27.2 . / 2.3 .80$ & $4.38 \pm 0.59$ & $4.36 \pm 0.73$ & 7 & & & & & & \\
\hline & 21.3 .80 & $2.67 \pm 1.44$ & $2.70 \pm 0.49$ & 2 & $0.297 \pm 0.009$ & 1.93 & 2 & 154 & & \\
\hline \multirow[t]{4}{*}{$\delta$} & 22.29 .8 .77 & $1.57 \pm 0.57$ & $10.20 \pm 2.96$ & 6 & & & & & & \\
\hline & $27.2 . / 2.3 .78$ & $0.35 \pm 0.03$ & $1.02 \pm 0.12$ & 2 & & & & & & \\
\hline & 13.6 .79 & 0.80 & 4.13 & 1 & & & & & & \\
\hline & 21.3 .80 & $0.57 \pm 0.05$ & $1.38 \pm 0.01$ & 2 & $0.186 \pm 0.036$ & 0.89 & 2 & 208 & & \\
\hline \multicolumn{11}{|c|}{ Korsfjord } \\
\hline Stage & Date & $\begin{array}{l}\text { Specific } \\
\text { trypsin }\end{array}$ & $\begin{array}{l}\text { Specific } \\
\text { amylase }\end{array}$ & $\mathrm{n}$ & Respiration & $\begin{array}{l}\text { Specific } \\
\text { respira- } \\
\text { tion }\end{array}$ & $\mathrm{n}$ & $\begin{array}{c}\text { Dry- } \\
\text { weight }\end{array}$ & Length & $\mathrm{n}$ \\
\hline \multirow[t]{2}{*}{$\mathrm{CV}_{\mathrm{d}}$} & 23. 8.-4.9.78 & 0 & $1.34 \pm 0.32$ & 5 & $0.048 \pm 0.004$ & 0.11 & 5 & 449 & $2.66 \pm 0.18$ & 34 \\
\hline & $21 . / 23.11 .78$ & $0.15 \pm 0.02$ & $0.64 \pm 0.25$ & 2 & $0.072 \pm 0.014$ & 0.18 & 3 & 445 & & \\
\hline \multirow[t]{2}{*}{$\mathrm{CV}_{\mathrm{s}}$} & 23. 8. -4.9 .78 & $2.16 \pm 0.09$ & $5.38 \pm 0$ & 2 & $0.128 \pm 0.025$ & 0.72 & 4 & 179 & $2.25 \pm 0.10$ & 16 \\
\hline & $21 . / 23.11 .78$ & 1.44 & 5.37 & 1 & 0.145 & 0.79 & 1 & 168 & & \\
\hline \multirow[t]{2}{*}{$\stackrel{9}{d}$} & 23.8.-4.9. 78 & 0 & $1.87 \pm 0.71$ & 5 & $0.102 \pm 0.023$ & 0.36 & 3 & 285 & $2.84 \pm 0.15$ & 15 \\
\hline & $21 . / 23.11 .78$ & 0 & $0.78 \pm 0.18$ & 3 & $0.115 \pm 0.005$ & 0.39 & 3 & 292 & & \\
\hline$q_{\mathrm{s}}$ & 23. 8. -4.9 .78 & $2.20 \pm 0.20$ & $6.97 \pm 1.14$ & 2 & 0.227 & & 1 & & $2.53 \pm 0.24$ & 10 \\
\hline
\end{tabular}


copepods did not show any escape reaction when touched with a laboratory needle. Several hours later they reacted with weak jerks and sluggish movements of their antennules and occasional abdomen quivering, but then fell back into a motionlessness. Their guts were always empty, performing very slow, irregular peristaltic movements. Faecal pellets were never pro- duced. The oilsac was conspicuous with a bright red tip on the posterior end. In March, CV were found in the whole water column. They swam actively, had full guts and produced faecal pellets.

In the Korsfjord, 2 populations were found in the samples taken in August and November. Deep samples consisted mostly of $\mathrm{CV}$ and circa $5 \%$ females.

Table 2. Calanus finmarchicus. Korsfjord. A Trypsin $\left(10^{-4} \mathrm{U}_{\mu \mathrm{g}^{-1}}\right)$ and amylase $\left(10^{-5} \mathrm{U}_{\mu \mathrm{g}^{-1}}\right)$ activities, respiration $\left(\mu \mathrm{l} \mathrm{O}_{2}\right.$ ind. ${ }^{-1} \mathrm{~h}^{-1}$, based on ETS) and faecal-pellet production of Copepodid stage $\mathrm{V}$ and females kept at 2 temperatures in the dark with food.

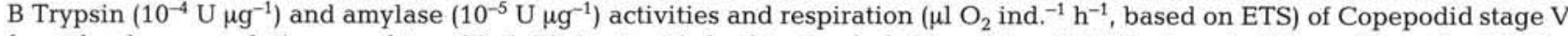
from the deep population caught on 23. 8. 78, kept with food in the dark (a) and in a light/dark cycle (b), or without food in the dark (c) at 2 temperatures

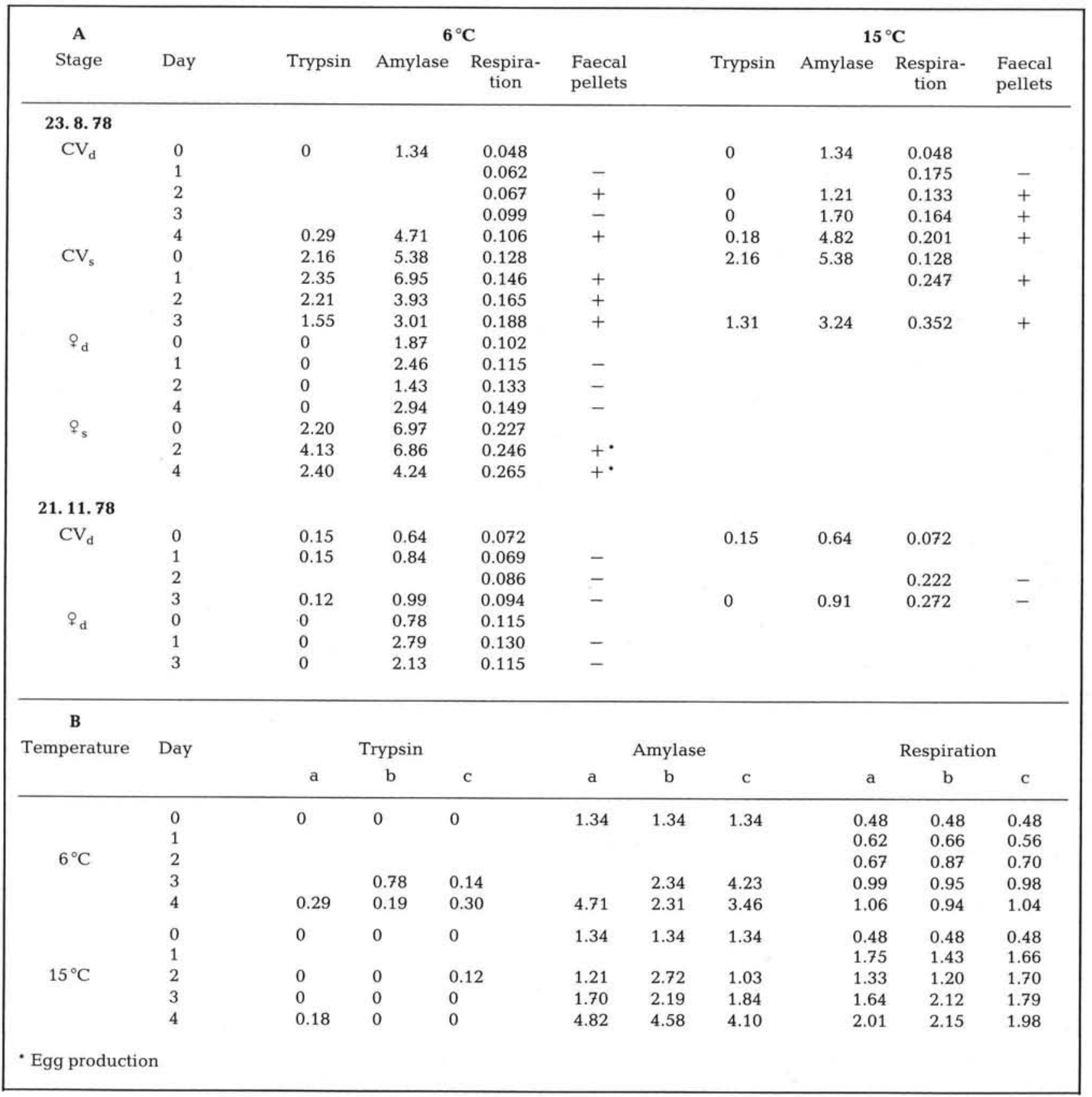


Both stages were rich in fat and showed the same behaviour as described above for CV from the Gullmarfjord. The surface population sampled at the same time exhibited a behaviour quite different from that of the deep population. Females and CV swam actively, had full guts but almost no lipid reserve.

Length measurements (Table 1) show that copepods from deep water in Korsfjord were larger than those from the surface population. CV from deep water had over twice the weight of those in the shallow-water population, although the higher lipid content of the former may have accounted for most of the differences. Copepods from the Gullmarfjord and the surface population of the Korsfjord were of the same length but CV from Gullmarfjord were somewhat heavier.

\section{Digestive enzymes and respiration}

In the Gullmarfjord, digestive enzymes and respiration of males, females and CV were studied (Table 1). In comparison with the spring value (May 1977, for details see Hirche, 1981), enzyme activities of CV during August and throughout the winter were greatly reduced. In June, activities were already approaching overwintering levels. Trypsin activity was lowest in overwintering $\mathrm{CV}$ and in males at all times of the year. Females had high activity levels both in winter and summer. Amylase followed a similar activity pattern to trypsin except that males in summer had activity levels similar to those of the $\mathrm{CV}$ and females.

There were also great differences between the respiration rates of CV in late spring (June 1979) and winter. Although respiration of overwintering $\mathrm{CV}$ was only $1 / 3$ to $1 / 5$ of that in summer these results cannot be used to investigate overwintering trends since they were obtained from measurements in different years.

In deep-living $\mathrm{CV}$ from the Korsfjord, digestive enzyme activities were similar to those of the Gullmarfjord. In addition, the females found in the deep population also had reduced activities.

The specific respiration rate of Korsfjord CV was only half of that of the Gullmarfjord CV, whereas the specific respiration rate of Korsfjord females was similar to that of the CV from Gullmarfjord.

The differences in behaviour between deep and surface populations noted above are reflected in differences in respiration rates and digestive enzyme activities of $\mathrm{CV}$ and females from the Korsfjord in summer.

\section{Experiments}

The effects of temperature, light and food upon digestive enzyme activity, respiration and develop- ment were studied in overwintering stages from Korsfjord and Gullmarfjord on different occasions (Tables 2 and 3).

\section{Korsfjord}

In the Korsfjord, differences between deep and surface populations remained throughout the experiments (Table $2 \mathrm{~A}$ ): the surface population immediately produced faecal pellets, females laid eggs, and digestive enzyme activities remained high. Respiration rates, however, increased in both populations at the 2 experimental temperatures. For females the increase was generally lower than for $\mathrm{CV}_{\text {; }}$ in November it was in both stages lower than in August.

$\mathrm{CV}$ from the deep population produced a few faecal pellets after 2 days only in August; in November no pellets were produced. In the deep population trypsin remained unchanged. Amylase in CV increased considerably in August, but only slightly in November. In females there was an increase in amylase activity in both months. Temperature did not influence digestive enzyme activities, but ETS activity was much higher at $15{ }^{\circ} \mathrm{C}$. In simultaneous 'light/dark experiments' and in starvation experiments in August (Table 2B) digestive enzymes and respiration did not differ markedly from comparable values obtained in the 'dark experiments'. Therefore, neither light conditions nor food influence digestive enzyme activities and respiration significantly.

\section{Gullmarfjord}

Experiments with $\mathrm{CV}$ from the Gullmarfjord were run over longer periods than those at Korsfjord on 3 occasions (Table 3 ). The time between the start of the experiment and the first appearance of adults as well as the mortality rate decreased from October to March (Table 4). At the higher temperature moulting occurred earlier. In October after about 2 wk at $15^{\circ} \mathrm{C}$ many CV were found lying on the bottom with their exuvia only partly shed and their antennules shrunk and distorted. Within a few days they all died. Very few moulted successfully and these all had deformities. Very often setae, especially on the caudal furca, were stuck together. At $6{ }^{\circ} \mathrm{C}$ the same happened a few days later. In December mortality was much lower than in October, but still most deaths occurred during moulting.

Respiration rates from all experiments are shown in Fig. 1. At $6{ }^{\circ} \mathrm{C}$, respiration rate increased from the initial level, but not consistently. At $15{ }^{\circ} \mathrm{C}$, the increase was more rapid and a plateau was reached within a few days; the plateau height varied on each occasion. 


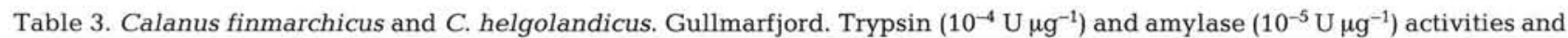
respiration $\left(\mu \mathrm{l} \mathrm{O}\right.$ ind. $^{-1} \mathrm{~h}^{-1}$, based on ETS) of Copepodid stage $\mathrm{V}$ kept at 2 temperatures in the dark respectively in a $12 / 12 \mathrm{~h}$ light/dark cycle without food

\begin{tabular}{|c|c|c|c|c|c|c|c|c|c|c|c|c|c|}
\hline \multirow{3}{*}{ Date } & \multirow{3}{*}{ Day } & \multicolumn{6}{|c|}{$6{ }^{\circ} \mathrm{C}$} & \multicolumn{6}{|c|}{$15^{\circ} \mathrm{C}$} \\
\hline & & \multicolumn{3}{|c|}{ Dark } & \multicolumn{3}{|c|}{ Light/dark } & \multicolumn{3}{|c|}{ Dark } & \multicolumn{3}{|c|}{ Light/dark } \\
\hline & & $\begin{array}{c}\text { Specific } \\
\text { trypsin }\end{array}$ & $\begin{array}{l}\text { Specific } \\
\text { amylase }\end{array}$ & $\begin{array}{l}\text { Respira- } \\
\text { tion }\end{array}$ & $\begin{array}{l}\text { Specific } \\
\text { trypsin }\end{array}$ & $\begin{array}{l}\text { Specific } \\
\text { amylase }\end{array}$ & $\begin{array}{l}\text { Respira- } \\
\text { tion }\end{array}$ & $\begin{array}{l}\text { Specific } \\
\text { trypsin }\end{array}$ & $\begin{array}{l}\text { Specific } \\
\text { amylase }\end{array}$ & $\begin{array}{l}\text { Respira- } \\
\text { tion }\end{array}$ & $\begin{array}{c}\text { Specific } \\
\text { trypsin }\end{array}$ & $\begin{array}{l}\text { Specific } \\
\text { amylase }\end{array}$ & $\begin{array}{l}\text { Respira- } \\
\text { tion }\end{array}$ \\
\hline \multirow[t]{11}{*}{6.10 .78} & $\begin{array}{l}0 \\
1\end{array}$ & 0.32 & 1.05 & $\begin{array}{l}0.102 \\
0.105\end{array}$ & 0.32 & 1.05 & 0.102 & 0.32 & 1.05 & 0.102 & 0.32 & 1.05 & 0.102 \\
\hline & 2 & 0.07 & & 0.146 & & & & & & 0.375 & 1.74 & 3.75 & 0.436 \\
\hline & 3 & 0.57 & & 0.142 & & & & & & & & & \\
\hline & 4 & 0.72 & 0.32 & & & & & & & 0.511 & 1.35 & 2.79 & 0.536 \\
\hline & 5 & 0.76 & 2.38 & 0.141 & 0.43 & 1.05 & & & & & & & \\
\hline & 6 & 0.88 & 4.58 & 0.179 & & & & & & & & & \\
\hline & 10 & 1.44 & 4.58 & 0.159 & 0.60 & 1.78 & 0.160 & 0.60 & 2.17 & 0.571 & 0.38 & 1.72 & 0.571 \\
\hline & 18 & 0.54 & & 0.181 & & & 0.206 & 0.26 & 4.32 & 0.584 & 1.50 & 1.29 & 0.547 \\
\hline & 22 & & & & 0.63 & 4.90 & & 0.34 & 1.34 & 0.572 & 0.68 & 1.62 & 0.557 \\
\hline & 28 & & & & 0.54 & & 0.223 & & & 0.624 & & & 0.653 \\
\hline & 34 & & & 0.305 & & & & & & & & & \\
\hline \multirow[t]{11}{*}{14.12 .78} & 0 & 0.42 & 1.42 & 0.076 & 0.42 & 1.42 & 0.076 & & & & 0.42 & 1.42 & 0.076 \\
\hline & 3 & & & & 0.42 & 0.87 & 0.083 & & & & 0.45 & 1.72 & 0.196 \\
\hline & 4 & & & & 0.44 & 1.63 & 0.086 & & & & 0.39 & 2.40 & 0.250 \\
\hline & 5 & & & & 0.40 & 1.03 & 0.110 & & & & 0.49 & 3.12 & 0.284 \\
\hline & 6 & & & & 0.38 & 0.96 & 0.106 & & & & 0.51 & 3.25 & 0.296 \\
\hline & 7 & & & & 0.43 & 1.59 & 0.118 & & & & 0.48 & 2.96 & 0.309 \\
\hline & 9 & & & & 0.61 & 2.03 & 0.101 & & & & 0.64 & 2.60 & 0.307 \\
\hline & 11 & & & & & 1.69 & 0.092 & & & & & & \\
\hline & 13 & & & & 0.49 & 1.15 & 0.103 & & & & & 1.70 & 0.334 \\
\hline & 20 & & & & & & 0.121 & & & & & & \\
\hline & 28 & & & & & & 0.120 & & & & & & \\
\hline \multirow[t]{5}{*}{21.3 .80} & 0 & & & & 0.41 & 1.75 & 0.087 & & & & 0.41 & 1.75 & 0.087 \\
\hline & 1 & & & & 0.47 & 1.78 & 0.117 & & & & 0.56 & & 0.363 \\
\hline & 3 & & & & 0.71 & 2.65 & 0.097 & & & & 1.10 & 5.25 & 0.411 \\
\hline & 5 & & & & 0.32 & 1.00 & 0.101 & & & & 0.62 & 2.82 & 0.443 \\
\hline & 7 & & & & 0.38 & & 0.123 & & & & & & 0.443 \\
\hline
\end{tabular}

Table 4. Calanus finmarchicus and C. helgolandicus. Gullmarfjord. Time between start of experiment and first appearance of adults and mortality after $28 \mathrm{~d}$. Based on 3 experiments with $\mathrm{CV}$

\begin{tabular}{|ccccc|}
\hline $\begin{array}{c}\text { Start of } \\
\text { experiment }\end{array}$ & $\begin{array}{c}\text { First adults } \\
\text { after (d) }\end{array}$ & \multicolumn{2}{c|}{$\begin{array}{c}\text { Mortality } \\
(\%)\end{array}$} \\
\hline & $\mathbf{6}^{\circ} \mathbf{C}$ & $\mathbf{1 5}^{\circ} \mathbf{C}$ & $\mathbf{6}^{\circ} \mathbf{C}$ & $\mathbf{1 5}^{\circ} \mathbf{C}$ \\
06.10 .78 & 22 & 18 & 95 & 100 \\
14.12 .78 & 11 & 7 & 40 & 65 \\
21.03 .80 & 1 & 1 & 10 & 25 \\
\hline
\end{tabular}

As at $6{ }^{\circ} \mathrm{C}$, respiration was highest in October and lowest in December.

Where no food is ingested, respiratory metabolism must be maintained at the expense of body material. This results in a reduction in dry weight; the degree of such reduction depends on respiratory rate and the substrate metabolized. In this situation it is reasonable to assume that pure lipid was metabolized (Kir- kesaether, 1977). The conversion factor $1 \mathrm{~g}$ fat $=$ $2041 \mathrm{ml} \mathrm{O}_{2}$ (Geigy, 1968) was therefore used to estimate the respiration rate from differences in dry weight (Table 5). The results reveal good agreement between estimated and measured values.

As regards digestive enzymes, with few exceptions trypsin activity remained consistently low (Table 3). There was, however, greater variation in amylase activity. This usually increased after a few days and

Table 5. Calanus finmarchicus and C. helgolandicus. Comparison between respiratory rates estimated from dry weight differences $(\Delta \mathrm{w})$ and measured respiratory rates of $\mathrm{CV}$ kept at $6{ }^{\circ} \mathrm{C}$ in the dark without food. Estimation is based on pure lipid metabolism. Conversion factor $1 \mathrm{~g}$ fat $=2041 \mathrm{ml} \mathrm{O}_{2}$

\begin{tabular}{|ccccc|}
\hline Date & $\begin{array}{c}\Delta t \\
(\mathrm{~d})\end{array}$ & $\begin{array}{c}\Delta \mathrm{W} \\
\left(\mu \mathrm{g} \mathrm{ind}^{-1}\right)\end{array}$ & \multicolumn{2}{c|}{$\begin{array}{c}\text { Respiratory rate } \\
\left(\mu \mathrm{O}_{2} \text { ind }^{-1} \mathrm{~h}^{-1}\right) \\
\text { measured } \\
\text { estimated }\end{array}$} \\
\hline $14.12 .78-12.01 .79$ & 29 & 19 & $0.076-0.121$ & 0.088 \\
$12.01 .79-20.02 .79$ & 39 & 68 & $0.121-?$ & 0.148 \\
\hline
\end{tabular}




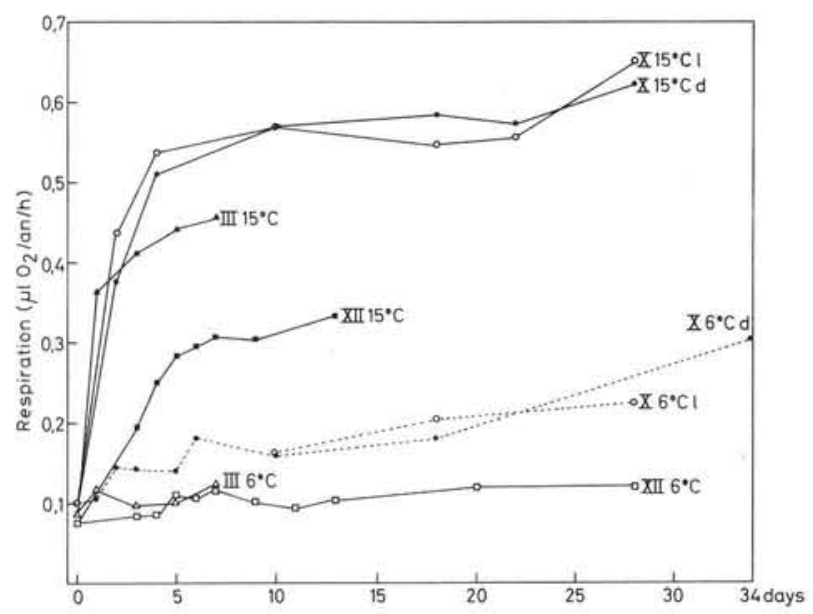

Fig. 1. Calanus finmarchicus and C. helgolandicus. Respiratory rates of copepodid stage $\mathrm{V}$ from Gullmarfjord kept at 2 temperatures in the dark (d) resp. in a 12/12 light/dark cycle (l) in March (III), October (X) and December (XII)

then tended to decrease again towards the end of an experiment, although in these experiments no food was offered.

The results from the October experiments suggest that light has a negligible effect on respiratory rate, digestive enzyme activity and developmental rate.

\section{DISCUSSION}

\section{Field study}

With regard to the literature, 3 observations reported here on overwintering stages of Calanus finmarchicus and C. helgolandicus are remarkable:

(1) The respiration rates of deep-living CV from both fjords investigated are the lowest hitherto reported (for comparison see Marshall, 1973).

(2) The torpid behaviour described in this study has not been noticed before in Calanus finmarchicus and C. helgolandicus, although it has been reported for $C$. hyperboreus by Conover (1962).

(3) Dry weight data of CV from the Korsfjord agree well with the data of Kirkesaether (1977) and are the highest reported so far. Marshall et al. (1934) found a maximum dry weight of $350 \mu \mathrm{g}$ individual $^{-1}$ in the Clyde Sea; other measurements from the English Channel (Bogorov, 1934; Cowey and Corner, 1963; Gatten et al., 1979), Loch Fyne (Orr, 1934), Bute Channel (Comita et al., 1966), Georges Bank and Gulf of Maine (Conover, 1960) were even lower.

A possible explanation for the fact that these observations have not been made before is separation of the
Calanus population into a surface-living and a deepliving population. Only the deep-living specimens show overwintering features. The existence of 2 vertically separated populations of Calanus finmarchicus and $C$. helgolandicus has been reported by Nicholls (1933) and Marshall et al. (1934) for the Clyde Sea, and by Østved (1955) and Krause (1978) for the southern Norwegian Sea.

When overwintering stages from both fjords are compared, torpidity and strongly reduced digestive enzyme activities characterise copepods from both fjords, whereas their weight-specific respiratory rate is lower and dry weight is much higher in the Korsfjord. These differences are not species dependent, as they were present in August when all CV in both fjords were of one species, Calanus finmarchicus.

A decrease in dry weight from 450 to $180 \mu \mathrm{g}$ individual $^{-1}$ from September to February was found by Kirkesaether (1977) for CV of Calanus finmarchicus in the Korsfjord. The respiration rates measured here would facilitate survival over a much longer period of time than required for this dry weight to be metabolised without feeding. For the lowest respiration rate measured and a decrease in dry weight down to values obtained during my expriments, the CV from Gullmarfjord could survive for only $120 \mathrm{~d}$. A possible explanation for the dry-weight differences may be a different food supply in the 2 fjords. Another factor that is different in the 2 fjords is water depth. Overwintering $\mathrm{CV}$ in the Korsfjord live much deeper than in the Gullmarfjord. In the open sea C. finmarchicus spends the winter in depths below $300 \mathrm{~m}$ and down to more than $1000 \mathrm{~m}$ (Sømme, 1934, Østved, 1955; Williams and Hopkins, 1976; Vives, 1978; Longhurst and Williams, 1979). Thus, environmental factors like pressure or light could affect metabolism in a way not yet understood.

In places like the Gullmarfjord the species considered here cannot overwinter. Hence the question arises: where do the $\mathrm{CV}$ found in winter come from? Studies of the population dynamics of Calanus finmarchicus and C. helgolandicus in the Gullmarfjord (Hirche, in press) showed that the formation of the overwintering stock commences at the end of May by accumulation of CV. In the Korsfjord, according to Matthews (quoted in Kirkesaether, 1977), overwintering $\mathrm{CV}$ are aggregating in June in deep water. This deep stock is built up throughout the summer. In the Gullmarfjord, however, in July both Calanus species have virtually disappeared, although by the end of August and during September and October large numbers of $\mathrm{CV}$ are found again, their origin is unclear and is discussed in detail by Hirche (in press). The same phenomenon has also been reported for the Irish Sea and the North Sea (Rees, 1949; Marshall and Orr, 1958). 


\section{Laboratory experiments}

In general overwintering stages of calanoid copepods do not recommence development until the end of winter. In the North Atlantic Ocean, Calanus finmarchicus starts moulting in December and January (Marshall and Orr, 1955). In the experiments reported here, behaviour and metabolism of CV were different from CV observed in the field at the same time. Amylase activities and respiratory rates increased and moulting took place under all experimental conditions but this was associated with high mortality in autumn and early winter. High mortality during moults in autumn was also reported by Raymont and Gross (1942). Moulting success was not affected by light, food or temperature, except for an accelerating effect at higher temperatures. Gardner (1972), working with overwintering $C$. plumchrus found that neither light nor the physical disturbance associated with changing the water were factors that could elicit moulting. Some other factors which may induce moulting and changes in the metabolism are stress due to changes in hydrostatic pressure during sampling, mechanical stimuli during sorting and sudden exposure to daylight. Mechanical stimuli seemed to be most important as an awakening factor for cyclopoid copepods in diapause (Nilssen and Elgmork, 1977).

The responses of $\mathrm{CV}$ collected at different times of the year differed under identical experimental conditions. Time between capture and onset of moulting, as well as mortality during the moulting process, decreased during autumn and winter, and the respiratory response to experimental temperatures was variable. Progressive decrease in the time-to-ecdysis of CV of Calanus finmarchicus through July until November was also described by Grigg and Bardwell (1982) from the Irish Sea. In contrast to the results presented here only low premoult mortality and a few unsuccessful moults occurred in their experiments throughout the year, while moulting of $\mathrm{CV}$ during autumn occurred much earlier. These observations indicate that some internal development takes place during the overwintering period. It appears that in areas like the Gullmarfjord it is only after the termination of this developmental phase that the overwintering stages are able to moult successfully. In other areas such as the Irish Sea the physiological changes during the state of overwintering do not appear to be as profound, so that moulting can take place more rapidly and throughout the year.

It is likely that overwintering metabolism and moulting are under hormonal control, since Carlisle and Pitman (1961) have reported seasonal differences in the neurosecretory cells of Calanus finmarchicus. Endocrine processes could act as the 'biological clock', that controls termination of the overwintering stage, as has been suggested by Banse (1964), Conover (1965) and Gardner (1972).

\section{CONCLUSIONS}

The results of the field studies and experiments presented here for Calanus helgolandicus and C. finmarchicus corroborate observations from other calanoid copepod species which indicate that overwintering $\mathrm{CV}$, under natural conditions, do not feed. Instead, their metabolism is low. They are torpid, the epithelium of the midgut (Hallberg and Hirche, 1980) and the activities of digestive enzymes (see also Tande and Slagstad, 1982) and trimethylamine monooxygenase (Strøm, 1979) are reduced. These adaptations allow survival in winter, providing sufficient fat reserves can be stored. The conditions necessary for such storage are, however, not known. Decreasing time between capture and onset of moulting, as well as increasing moulting success during autumn and winter, suggest that overwintering behaviour, metabolism and moulting are to a large extent under endocrine control, and are possibly triggered by the photoperiod (Grigg and Bardwell, 1982).

Many of these observations agree with descriptions of overwintering freshwater cyclopoids (Elgmork and Nilssen, 1978) and insects in diapause (Mansingh, 1971). This subject requires further research.

Acknowledgements. I wish to thank the directors and staff of Kristinebergs Marinbiologiska Station (Fiskebäckskil, Sweden) and of the Marinbiologiska Stasjon Bergen (Espegrend Norway) for sampling and working facilities. The help of I. Everson in manuscript translation is much appreciated. The investigation was supported by the 'Deutsche Forschungsgemeinschaft' within the programme 'Upwelling in the Sea'.

\section{LITERATURE CITED}

Andersson, J., Hernroth, L., Lindahl, O. (1979). Västkustprojektet - Pelagialdel I. Forskningsreport 1978, Marinbiologisk Station Kristineberg, Sweden

Andrews, K. J. H. (1966). The distribution and life history of Calanoides acutus (Giesbrecht). 'Discovery' Rep. 34: 117-162

Banse, K. (1964). On the vertical distribution of zooplankton in the sea. Progr. Oceanogr. 2: 53-125

Bogorov, B. G. (1934). Seasonal changes in biomass of Calanus finmarchicus in the Plymouth area in 1930. J. mar. biol. Ass. U. K. 19: 585-611

Butler, E. J., Corner, E. D. S., Marshall, S. M. (1970). On the nutrition and metabolism of zooplankton. VII. Seasonal survey of nitrogen and phosphorus excretion by Calanus in the Clyde-Sea area. J. mar. biol. Ass. U. K. 50: 525-560

Carlisle, D. B., Pitman, W. J. (1961). Diapause, neurosecretion and hormones in Copepoda. Nature, Lond. 190: 827-828

Comita, G. W., Marshall, S. M., Orr, A. P. (1966). On the 
biology of Calanus finmarchicus. XIII. Seasonal change in weight, calorific value and organic matter. J. mar. biol. Ass. U. K. 46: 1-17

Conover, R. J. (1956). Oceanography of Long Island Sound 1952-1954. VI. Biology of Acartia clausi and A. tonsa. Bull. Bingham Oceanogr. Coll. 15: 156-233

Conover, R. J. (1960). The feeding behaviour and respiration of some marine planktonic crustacea. Biol. Bull. mar. biol. Lab., Woods Hole 119: 399-415

Conover, R. J. (1962). Metabolism and growth in Calanus hyperboreus in relation to its life cycle. J. Cons. int. Expl. Mer 153: 190-197

Conover, R. J. (1965). Notes on the moulting cycle, development of sexual characters and sex ratio in Calanus hyperboreus. Crustaceana 8: 308-320

Corner, E. D. S., Head, R. N., Kilvington, C. C., Marshall, S. M. (1974). On the nutrition and metabolism of zooplanktion. IX. Studies relating to the nutrition of overwintering Calanus. J. mar. biol. Ass. U. K. 54: 319-331

Cowey, C. B., Corner, E. D. S. (1963). On the nutrition and metabolism of zooplanktion II. The relationship between the marine copepod Calanus helgolandicus and particulate material in Plymouth sea water in terms of amino acid composition. J. mar. biol. Ass. U. K. 43: 495-511

Elgmork, K., Nilssen, J. P. (1978). Equivalence of copepod and insect diapause. Verh. int. Verein. theor. angew. Limnol. 20: 2511-2517

Fleminger, A., Hülsemann, K. (1977). Geographical range and taxonomic divergence in North Atlantic Calanus $(C$. helgolandicus, C. finmarchicus, and C. glacialis). Mar. Biol. 40: 233-248

Fulton, J. (1973). Some aspects of the life history of Calanus plumchrus in the Strait of Georgia. J. Fish. Res. Bd Can. 30: $811-815$

Gardner, G. A. (1972). The distribution of the life history stages of Calanus plumchrus (Marukawa) in the Strait of Georgia. M. Sci. thesis, Institute of Oceanography, Univ. British Columbia

Gatten, R. R., Corner, E. D. S., Kilvington, C. C., Sargent, J. R. (1979). A seasonal survey of the lipids in Calanus helgolandicus Claus from the English Channel. In: Naylor, E., Hartnoll, R. G. (eds.) Cyclic phenomena in marine plants and animals. Pergamon Press, Oxford, New York, p. 275-284

Geigy, J. R. (ed.) (1968). Documenta Geigy. Wissenschaftliche Tabellen, 7. Auflage. Basel

Grigg, H., Bardwell, S. J. (1982). Seasonal observations on moulting and maturation in stage $\mathrm{V}$ copepodites of Calanus finmarchicus from the Firth of Clyde. J. mar. biol. Ass. U. K. 62: 315-327

Guillard, R. R. L., Ryther, J. H. (1962). Studies of marine planktonic diatoms. I. Cyclotella nana (Hustedt) and Detonula confervacea (Cleve) (Gran). Can. J. Microbiol. 8: 229-239

Hallberg, E., Hirche, H. J. (1980). Differentiation of mid-gut in adults and overwintering copepodids of Calanus finmarchicus and C. helgolandicus. J. exp. mar. Biol. Ecol. 48: 283-295

Harvey, H. W. (1950). On the production of living matter in the sea off Plymouth. J. mar. biol. Ass. U. K. 29: 97-137

Hirche, H. J. (1981). Digestive enzymes of copepodids and adults of Calanus finmarchicus and C. helgolandicus in relation to particulate matter. Kieler Meeresforsch., Sonderh. 5: 174-185

Hirche, H. J. (in press). Seasonal distribution of Calanus finmarchicus and C. helgolandicus in a Swedish fjord. Crustaceana, Suppl.
Kirkesaether, P. (1977). Biomasseundersøkelse av Calanus finmarchicus i Korsfjorden 1974-1975, belyst ved kalorimetri of biokjemiske analyser. Hovedfagsoppgave, Univ. Bergen

Krause, M. (1978). Zur Vertikalverteilung des Makroplanktons in der südlichen Norwegischen See. Dissertation Univ. Hamburg

Longhurst, A., Williams, R. (1979). Materials for plankton modelling: vertical distribution of Atlantic zooplankton in summer. J. Plankton Res. 1: 1-28

Lowry, O. H., Rosenbrough, N. J., Farr, L., Randall, R. J. (1951). Protein measurement with the Folin phenol reagent. J. Biol. Chem. 193: 265-275

Mansingh, A. (1971). Physiological classification of dormancies in insects. Can. Ent. 103: 983-1009

Marshall, S. M. (1973). Respiration and feeding in copepods. Adv. mar. Biol. 11: 57-120

Marshall, S. M., Nicholls, A. G., Orr, A. P. (1934). On the biology of Calanus finmarchicus. V. Seasonal distribution, size, weight and chemical composition in Loch Striven in 1933, and their relation to the phytoplanktion. J. mar. biol. Ass. U. K. 19: 793-827

Marshall, S. M., Orr, A. P. (1955). The biology of a marine copepod Calanus finmarchicus Gunnerus. Oliver \& Boyd, Edinburgh

Marshall, S. M., Orr, A. P. (1958). On the biology of Calanus finmarchicus. X. Seasonal changes in oxygen consumption. J. mar. biol. Ass. U. K. 37: 459-472

Matthews, J. B. L., Sands, N. J. (1973). Ecological studies on the deep-water pelagic community of Korsfjorden, western Norway. The topography of the area and its hydrography in 1968-1972, with a summary of the sampling programs. Sarsia 52: 29-51

Nicholls, A. G. (1933). On the biology of Calanus finmarchicus. III. Vertical distribution and diurnal migration in the Clyde-Sea area. J. mar. biol. Ass. U. K. 19: 139-164

Nilssen, J. P., Elgmork, K. (1977). Cyclops abyssorum - life cycle dynamics and habitat selection. Memorie Ist. ital. Idrobiol. 34: 197-238

Omori, M. (1970). Variations of length, weight, respiratory rate, and chemical composition of Calanus cristatus in relation to its food and feeding. In: J. H. Steele (ed.) Marine food chains. Berkeley, p. 174-181

Orr, A. P. (1934). On the biology of Calanus finmarchicus. IV. Seasonal change in the weight and chemical composition in Loch Fyne. J. mar. biol. Ass. U. K. 19: 613-632

Østvedt, O. J. (1955). Zooplankton investigations from weather-ship ' $\mathrm{M}$ ' in the Norwegian Sea. Hvalradets Skrifter 40: 1-93

Owens, T. G., King, F. D. (1975). The measurement of respiratory electron transport system activity in marine zooplankton. Mar. Biol. 30: 27-36

Raymont, J. E. G., Gross, F. (1942). On the feeding and breeding of Calanus finmarchicus under laboratory conditions. Proc. Soc. Edinb., B 61: 267-287

Rees, C. B. (1949). Continuous plankton records: the distribution of Calanus finmarchicus (Gunn.) and its two forms in the North Sea, 1938-1939. Hull Bull. mar. Ecol. 2: 215-275

Samain, J. F., Daniel, J. Y., LeCoz, J. R. (1977). Trypsine, amylase et protéines du zooplancton: Dosage automatique et manuel. J. exp. mar. Biol. Ecol. 29: 279-289

Sømme, J. (1934) Animal plankton of the Norwegian coast waters and the open sea. I. Production of Calanus finmarchicus (Gunner) and Calanus hyperboreus (Krøyer) in the Lofoten area. FiskDir. Skr. (Ser. Havunders.) 4: 1-163

Street, H. V., Close, J. R. (1965). Determination of amylase activity in biological fluids. Clin. Chim. Acta 1: 256-268 
Strøm, A. R. (1979). Biosythesis of trimethylamine oxide in Calanoid copepods. Seasonal changes in trimethylamine monooxygenase activity. Mar. Biol. 51: 33-40

Tande, K. S., Slagstad, D. (1982). Ecological investigation on the zooplankton community of Balsfjorden, northern Norway. Seasonal and short-time variations in enzyme activity in copepodite stage V and VI males and females of Calanus finmarchicus Gunnerus. Sarsia 67: 63-68
Ussing, H. H. (1938). The biology of some important plankton animals in the fjords of East Greenland. Meddr Grønland 100: $1-103$

Vives, F. (1978). Sobre la distribución de Calanus helgolandicus (Claus) en el Mediterráneo occidental. Res. Exp. Cient. B/O Corride 7 : 83-92

Williams, R., Hopkins, C. C. (1976). Sampling at Ocean Weather Station INDIA in 1974. Annls biol., Copenh. 31: $57-60$

This paper was submitted to the editor; it was accepted for printing on January, 30, 1983 